\title{
ELOC wt Allele
}

National Cancer Institute

\section{Source}

National Cancer Institute. ELOC wt Allele. NCI Thesaurus. Code C115422.

Human ELOC wild-type allele is located in the vicinity of $8 q 21.11$ and is approximately 33 $\mathrm{kb}$ in length. This allele, which encodes elong in-C protein, is involved in the promotion of transcriptional elongation. 